\title{
Utilization of ileal digestible amino acids by growing pigs: methionine
}

\author{
BY E. S. BATTERHAM, L. M. A NDERSEN AND D. R. BAIGENT* \\ NSW Agriculture, Wollongbar Agricultural Institute, Wollongbar, New South Wales 2477, \\ Australia
}

(Received 31 July 1992 - Accepted 9 January 1993)

\begin{abstract}
An experiment was conducted to determine the utilization of ileal digestible methionine by growing pigs. Three methionine-deficient diets (0.09 g ileal digestible methionine/MJ digestible energy (DE)) were formulated using cottonseed meal, meat-and-bone meal and soya-bean meal respectively as the only source of methionine in the diet. An additional three diets were formulated with supplements of methionine to confirm that methionine was limiting in the first three diets. The growth performance and retention of methionine by pigs given the six diets over the $20-45 \mathrm{~kg}$ growth phase was then determined. Growth rates $(\mathrm{g} / \mathrm{d})$ of pigs given the three diets formulated to $0.09 \mathrm{~g}$ ileal digestible methionine/MJ DE were significantly different $(P<0.01)$ : cottonseed meal 411 , meat-and-bone meal 442 , soya-bean meal 496 (SED 24.6). The response of pigs to the addition of methionine confirmed that methionine was limiting in these diets. Crude protein $(\mathrm{N} \times 6.25)$ deposited by the pigs $(\mathrm{g} / \mathrm{d})$ was significantly higher $(P<0.05)$ for those given soya-bean meal (61) and meat-and-bone meal (57) relative to cottonseed meal (47;SED 3.3). The proportion of ileal digestible methionine retained by pigs given the three protein concentrates was: cottonseed meal 0.39 , meat-and-bone meal 0.45 , soya-bean meal 0.47 (SED 0.019). These results indicate that values for the ileal digestibility of methionine in protein concentrates do not reflect the proportion of methionine that can be utilized by the pig. It appears that, with heat-processed meals, a considerable proportion of the methionine is absorbed in a form(s) that is (are) inefficiently utilized.
\end{abstract}

Ileal digestibility: Methionine: Pigs

The ileal digestibility of amino acids is commonly used to estimate the availability of amino acids for the growing pig. However, values for the ileal digestibility of lysine and threonine have been shown to be unsuitable for formulating diets containing heat-processed meal as a considerable portion of these amino acids appear to be absorbed in a form(s) that is (are) inefficiently utilized (Batterham et al. $1990 a$; Beech et al. 1991). It appears that ileal digestibility values for lysine and threonine overestimate availability in heat-damaged meals.

Little is known about the relationship between ileal digestibility and availability of other essential amino acids. Leibholz (1985) reported that the estimated retention of ileal digestible methionine by weaner pigs fed on five diets ranged from 0.97 to 1.07 and suggested that the ileal digestibility assay could be used to estimate methionine availability. If this is the case then amino acids may vary in their susceptibility to processing damage and methionine may be less susceptible than lysine and threonine.

The aim of the present experiment was to determine whether ileal digestibility values for

* Present Address: Department of Food and Agriculture, Institute for Sustainable Agriculture, Tatura, Victoria 3616, Australia. 
methionine were suitable for formulating diets, and to measure the retention of ileal digestible methionine from different protein concentrates by growing pigs.

\section{EXPERIMENTA L}

Protein concentrates

The three protein concentrates used were a 'prepress' solvent-extracted cottonseed meal, a meat-and-bone meal and a 'prepress' solvent-extracted soya-bean meal (Table 1). These three meals covered the range of estimated availability of lysine in protein concentrates (Standing Committee on Agriculture, 1987). Cottonseed meal has a low estimated availability of lysine ( $0 \cdot 40)$. It contains no antinutritional factors for pigs, other than free gossypol. This can be inactivated by the addition of $\mathrm{FeSO}_{4}$ to the diet, which binds the free gossypol (Tanksley \& Knabe, 1981). Pigs can tolerate $100 \mathrm{mg}$ free gossypol $/ \mathrm{kg}$ in the diet without effect, or at least $500 \mathrm{mg} / \mathrm{kg}$ with $\mathrm{FeSO}_{4}$ (free gossypol-Fe; $1: 1, \mathrm{w} / \mathrm{w}$ ). This is over twice the levels of free gossypol that were used in the present studies $(166 \mathrm{mg} / \mathrm{kg})$. Meatand-bone meal is of medium lysine availability (0.70). Provided $\mathrm{Zn}$ and Fe levels are adequate, pigs can tolerate the $\mathrm{Ca}$ contributed by these meals. Soya-bean meal is of high lysine availability $(0.88)$ and when adequately processed contains no antinutritional factors for pigs. The ileal digestibility of amino acids in these concentrates was determined previously with pigs fitted with a ' $T$ '-shaped cannula (Batterham et al. 1990a). The digestible energy (DE) content of the three protein concentrates was determined previously (Batterham et al. 1990 a) and the DE content of the other ingredients was estimated from previous determinations at this Institute.

\section{Diets}

Three diets were formulated to contain $0.09 \mathrm{~g}$ ileal digestible methionine/MJ DE (diets 1-3; Table 2). This level of methionine was chosen after considering the relationship between methionine and lysine. In previous studies with lysine a level of $0.36 \mathrm{~g}$ ileal digestible lysine/MJ DE was used as it represents an area where the growth rate of the pig responds in a linear manner to lysine concentration, but it is near the area where lysine retention plateaus (Batterham et al. 1990 b). A similar relationship was assumed for methionine with the selected level of $0.09 \mathrm{~g}$ ileal digestible methionine/MJ DE based on the methionine requirement being approximately 0.3 of lysine needs (Fuller $\&$ Wang, 1987). To ensure that methionine was the limiting amino acid in the diet, supplements of other essential amino acids were added to provide at least a 0.3 surplus, relative to methionine, according to the estimate of the Agricultural Research Council (1981), Fuller \& Wang (1987) and as estimated by computer simulation studies using the 'Auspig' model (Black et al. 1986) for the Wollongbar genotype. Diets 4-6 (Table 2) were supplemented with methionine to verify that methionine was limiting in diets $1-3$.

The cottonseed meal contained 12500 and $640 \mathrm{mg}$ total and free gossypol $/ \mathrm{kg}$ respectively and $\mathrm{FeSO}_{4}$ was added to inactivate any effects that the free gossypol may have on the pigs (Tanksley \& Knabe, 1981).

\section{Animals and procedures}

The six diets were arranged in a randomized block design. Ten Large White pigs (five male, five female) were allotted per diet. The pigs were blocked on 7-week weight, sex and position in the experimental facilities. The pigs were penned individually and water was supplied by nipple drinkers.

Dietary treatments were introduced when the pigs reached $20 \mathrm{~kg}$ live weight. The diets 
Table 1. Composition ( $\mathrm{g} / \mathrm{kg}$, air-dry basis) of the cottonseed meal, meat-and-bone meal and soya-bean meal

\begin{tabular}{|c|c|c|c|}
\hline & Cottonseed meal & Meat-and-bone meal & Soya-bean meal \\
\hline Crude protein $(\mathrm{N} \times 6.25)$ & 408 & 525 & 463 \\
\hline Dry matter & 885 & 953 & 883 \\
\hline Light petroleum (b.p. $40-60^{\circ}$ ) extract & 17 & 95 & 14 \\
\hline Fibre: Crude & 102 & - & 43 \\
\hline Neutral - detergent & 296 & - & 111 \\
\hline Ash & 63 & 323 & 66 \\
\hline \multicolumn{4}{|l|}{ Amino acids } \\
\hline Aspartic acid & $39 \cdot 7$ & $36 \cdot 0$ & $53 \cdot 2$ \\
\hline Threonine & 14.9 & 16.8 & $19 \cdot 2$ \\
\hline Serine & 20.6 & $22 \cdot 4$ & $25 \cdot 3$ \\
\hline Glutamic acid & $86 \cdot 1$ & $64 \cdot 2$ & $85 \cdot 9$ \\
\hline Glycine & 17.7 & 77.4 & $20 \cdot 1$ \\
\hline Alanine & 16.7 & $42 \cdot 7$ & $20 \cdot 2$ \\
\hline Cystine & 8.5 & $6 \cdot 3$ & $9 \cdot 1$ \\
\hline Valine & $15 \cdot 5$ & $18 \cdot 2$ & $16 \cdot 8$ \\
\hline Methionine & $6 \cdot 4$ & $7 \cdot 7$ & $7 \cdot 0$ \\
\hline Isoleucine & $11 \cdot 7$ & $12 \cdot 1$ & 17.5 \\
\hline Leucine & $25 \cdot 1$ & 28.9 & $35 \cdot 0$ \\
\hline Tyrosine & 11.8 & $11 \cdot 0$ & $16 \cdot 0$ \\
\hline Phenylalanine & 21.6 & $15 \cdot 8$ & $22 \cdot 9$ \\
\hline Histidine & $13 \cdot 5$ & $13 \cdot 2$ & 13.9 \\
\hline Lysine & $19 \cdot 7$ & 25.6 & $26 \cdot 9$ \\
\hline Arginine & $47 \cdot 9$ & $39 \cdot 5$ & $35 \cdot 4$ \\
\hline Tryptophan & $5 \cdot 3$ & 2.7 & 6.8 \\
\hline $\begin{array}{l}\text { Apparent ileal digestibility of } \\
\text { methionine (proportion of total) }\end{array}$ & 0.79 & 0.86 & 0.91 \\
\hline
\end{tabular}

were offered at a feeding scale of three times maintenance $(3 \times(0.5 \mathrm{MJ} \mathrm{DE} / \mathrm{kg}$ metabolic body weight $\left.\left(\mathrm{W}^{0.75}\right)\right)$. The pigs were fed every $3 \mathrm{~h}$ with an automatic feeder to ensure the utilization of the added free amino acids (Batterham \& Murison, 1981). The feed was offered dry and daily rations were adjusted weekly.

The pigs were slaughtered by electric stunning after reaching a minimum weight of $45 \mathrm{~kg}$. The blood was collected and the viscera washed to remove undigested material. The blood and washed viscera were then combined and frozen. The carcasses (with hair) were washed clean with water, split longitudinally down the middle of the vertebrae and the left side stored at $-15^{\circ}$. These were then ground, mixed, sampled and freeze-dried before chemical analyses. The mixed blood and washed viscera were processed in a similar manner.

In order to determine nutrient retentions, five male and five female pigs were slaughtered at the commencement of the experiment ( $20 \mathrm{~kg}$ live weight) and the chemical composition of the blood plus washed viscera and whole carcasses determined in a similar manner as the pigs slaughtered at $45 \mathrm{~kg}$ live weight.

Pig response was assessed in terms of daily live-weight gain, food conversion ratio (FCR), backfat thickness $\left(\mathrm{P}_{2}\right)$, empty body weight: final live weight, gain/d and FCR on an empty body weight basis, protein, fat and energy content in the empty body, protein, fat and energy deposition/d, protein, fat and energy deposition:DE intake, protein retention:protein intake, methionine retention:total methionine intake and methionine retention:apparent ileal digestible methionine intake.

The following factors were used in the previously-described calculations: 6.25 to convert 
Table 2. Composition ( $\mathrm{g} / \mathrm{kg}$, air-dry basis) of the diets formulated to 0.09 or $0.12 \mathrm{~g}$ ileal digestible methionine/MJ digestible energy

\begin{tabular}{|c|c|c|c|c|c|c|}
\hline Diet no.... & 1 & 2 & 3 & 4 & 5 & 6 \\
\hline \multicolumn{7}{|l|}{ Components } \\
\hline Cottonseed meal & 260 & 一 & - & 260 & - & - \\
\hline Meat-and-bone meal & - & 207 & - & - & 207 & - \\
\hline Soya-bean meal & - & - & 223 & - & - & 223 \\
\hline DL-Methionine & - & 一 & - & 0.46 & $0 \cdot 48$ & 0.49 \\
\hline Amino acids* & $13 \cdot 4$ & $22 \cdot 2$ & $9 \cdot 28$ & $13 \cdot 4$ & $22 \cdot 2$ & $9 \cdot 28$ \\
\hline Mineral and vitamin premix $\dagger$ & 5 & $10 \cdot 1$ & 5 & 5 & $10 \cdot 1$ & 5 \\
\hline Dicalcium phosphate & 30 & - & 30 & 30 & - & 30 \\
\hline $\mathrm{FeSO}_{4} \cdot 7 \mathrm{H}_{2} \mathrm{O}$ & 0.85 & $0 \cdot 25$ & - & 0.85 & 0.25 & - \\
\hline Solka floc & - & 20 & - & - & 20 & - \\
\hline Soya-bean oil & 15 & 15 & 15 & 15 & 15 & 15 \\
\hline Sucrose & $675 \cdot 75$ & $725 \cdot 45$ & $717 \cdot 72$ & 675.29 & 72497 & $717 \cdot 23$ \\
\hline \multicolumn{7}{|l|}{ Composition } \\
\hline DE (estimated) $(\mathrm{MJ} / \mathrm{kg})$ & $14 \cdot 7$ & $15 \cdot 19$ & $15 \cdot 62$ & $14 \cdot 7$ & $15 \cdot 19$ & 15.62 \\
\hline \multicolumn{7}{|l|}{ Ileal digestible methionine } \\
\hline $\mathrm{g} / \mathrm{kg}$ & $1 \cdot 33$ & $1 \cdot 37$ & $1 \cdot 41$ & 1.76 & 1.82 & 1.87 \\
\hline $\mathrm{g} / \mathrm{MJ} \mathrm{DE}$ & 0.09 & 0.09 & 0.09 & 0.12 & 0.12 & $0 \cdot 12$ \\
\hline $\begin{array}{l}\text { Essential: non-essential } \\
\text { amino acids }\end{array}$ & $41: 59$ & $43: 57$ & $42: 58$ & $41: 59$ & $43: 57$ & $42: 58$ \\
\hline
\end{tabular}

DE, digestible energy.

* Contributed the following $(\mathrm{g} / \mathrm{kg})$ to the cottonseed, meat-and-bone meal and soya-bean meal diets respectively: L-threonine $1 \cdot 62,2 \cdot 15,1 \cdot 2$, L-valine $1 \cdot 5,2 \cdot 3,1 \cdot 9$, L-isoleucine $1 \cdot 3,2 \cdot 15,0 \cdot 53$, L-leucine $1 \cdot 9,2 \cdot 9,0 \cdot 4$, Lphenylalanine $0 \cdot 8,4 \cdot 2,0 \cdot 63$, L-histidine $0 \cdot 7,1 \cdot 75,0 \cdot 95$, L-tryptophan $0 \cdot 62,1 \cdot 01,0 \cdot 37$, L-cystine $0 \cdot 2,1 \cdot 3,0 \cdot 53$, L-lysine hydrochloride $4 \cdot 76,4 \cdot 44,2 \cdot 77$.

$\dagger$ Contributed the following (mg/kg diet): Fe 60, $\mathrm{Zn} \mathrm{100,} \mathrm{Mn} \mathrm{30,} \mathrm{Cu} \mathrm{5,} \mathrm{I} \mathrm{2,} \mathrm{NaCl} 2 \cdot 8 \mathrm{~g}$, Se $0 \cdot 15$, retinol equivalent $960 \mu \mathrm{g}$, cholecalciferol $12 \mu \mathrm{g}, \alpha$-tocopherol 20 , thiamine 1.5 , riboflavin 3 , nicotinic acid 14, pantothenic acid 10 , pyridoxine $2 \cdot 5$, cyanocobalamin $15 \mu \mathrm{g}$, menadione 2 (as menadione sodium bisulphite), pteroylmonoglutamic acid 2, choline 500, ascorbic acid 10 and biotin $0 \cdot 1$. Additional supplements of $\mathrm{ZnO}(100 \mathrm{mg} / \mathrm{kg})$ and $\mathrm{K}_{2} \mathrm{SO}_{4}(5 \mathrm{~g} / \mathrm{kg})$ were added to diets 2 and 5 .

$\mathrm{N}$ to protein (Agricultural Research Council, 1981); 0.913 (female) and 0.907 (male) to convert initial live weight to estimated initial empty body weight; $8 \cdot 2$ (female) and $7 \cdot 7$ (male) to calculate the energy $(\mathrm{MJ} / \mathrm{kg}$ ) and 141 (female) and 135 (male) to calculate the protein $(\mathrm{g} / \mathrm{kg})$ in the empty bodies of the pigs at the commencement of the experiment (these factors were determined on the five males and five females slaughtered at $20 \mathrm{~kg}$ live weight). Energy stored as protein was calculated as protein $(\mathrm{kg}) \times 24 \cdot 2$ (Jordan \& Brown, 1970). Fat content was calculated as (total energy - protein energy)/39.6 (Burlacu et al. 1973). The methionine content of composite samples of the blood plus viscera and of the carcasses from the ten pigs for each diet, and for the ten pigs slaughtered at $20 \mathrm{~kg}$ live weight, were determined.

The results were analysed by analysis of variance as a $3 \times 2$ factorial and dietary means separated by least significant difference (LSD).

\section{Chemical analyses}

The techniques used were as reported by Batterham et al. (1990 b). Performic acid oxidation (Mason et al. (1980) as used by Andrews \& Baldar (1985) but modified to use $50 \mathrm{ml}$ sealable hydrolysis tubes) was used before acid-hydrolysis for the determination of methionine in all samples. 


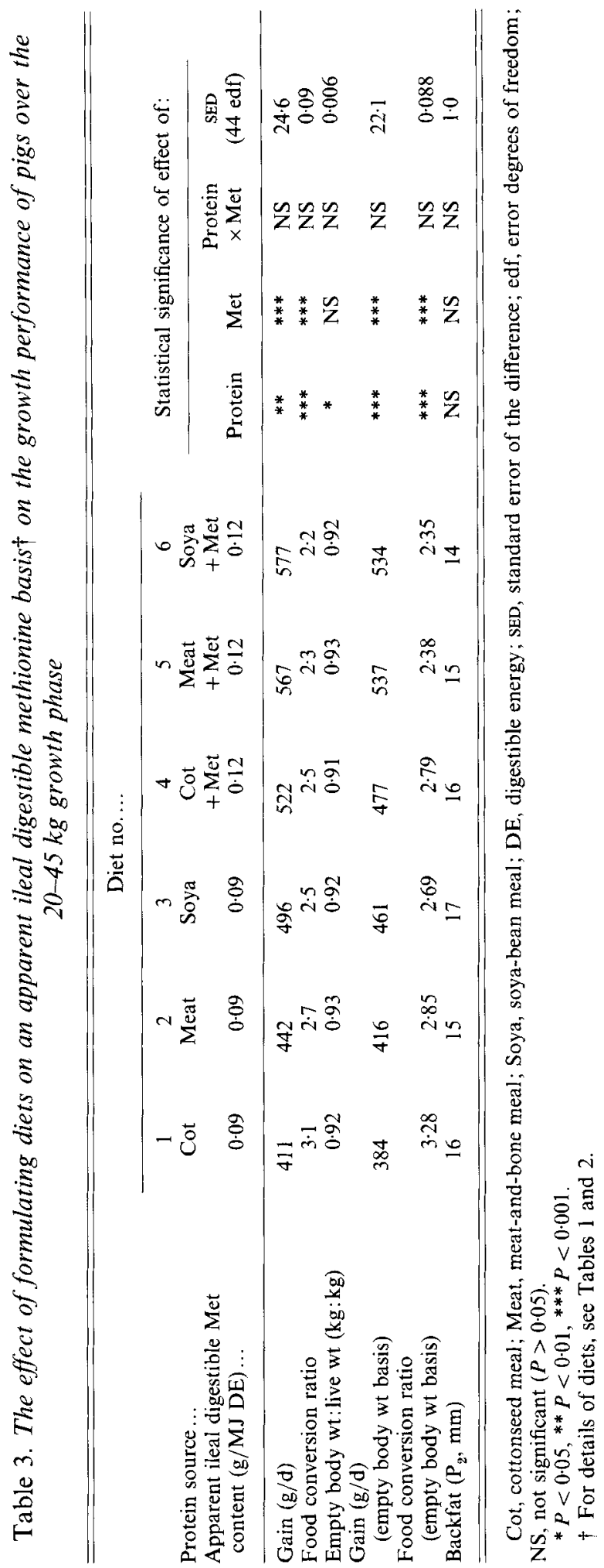




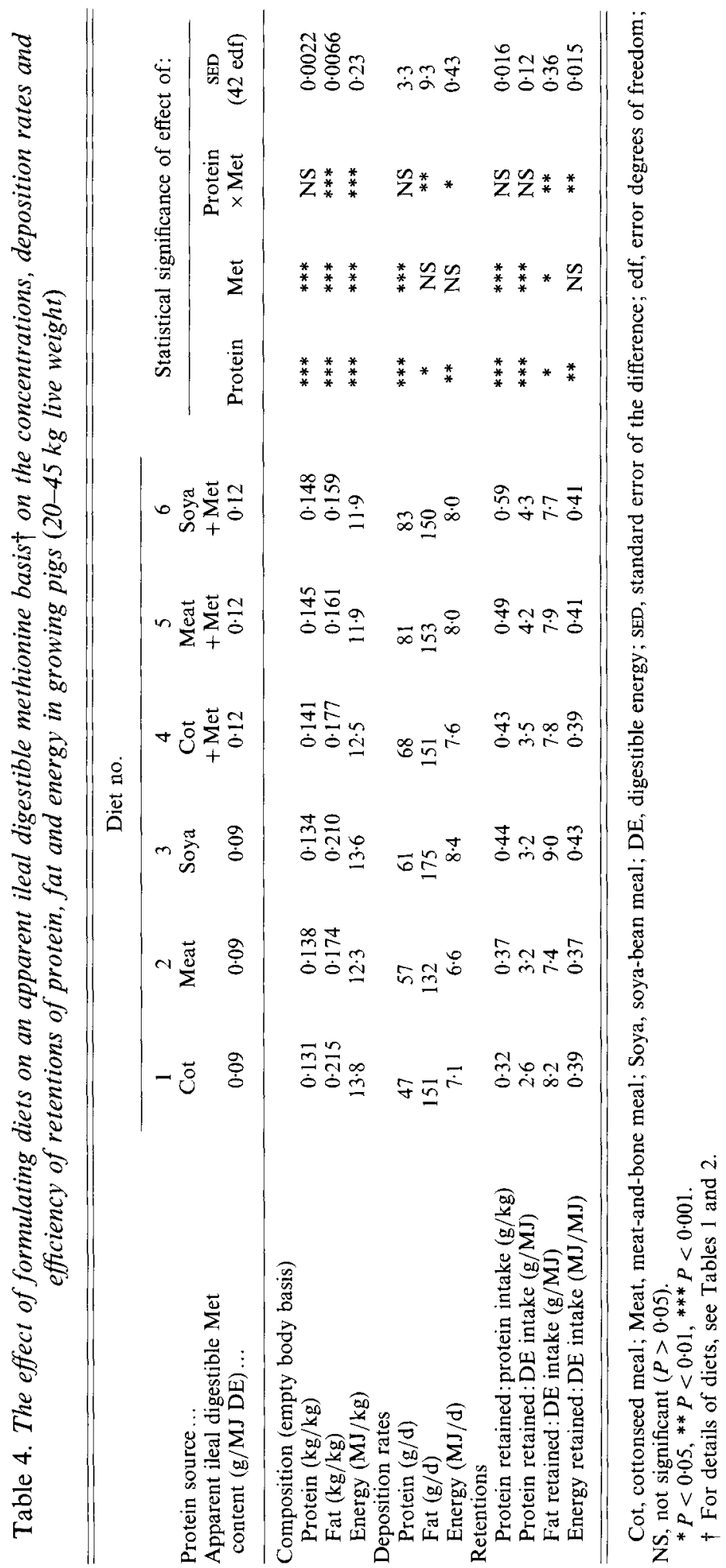




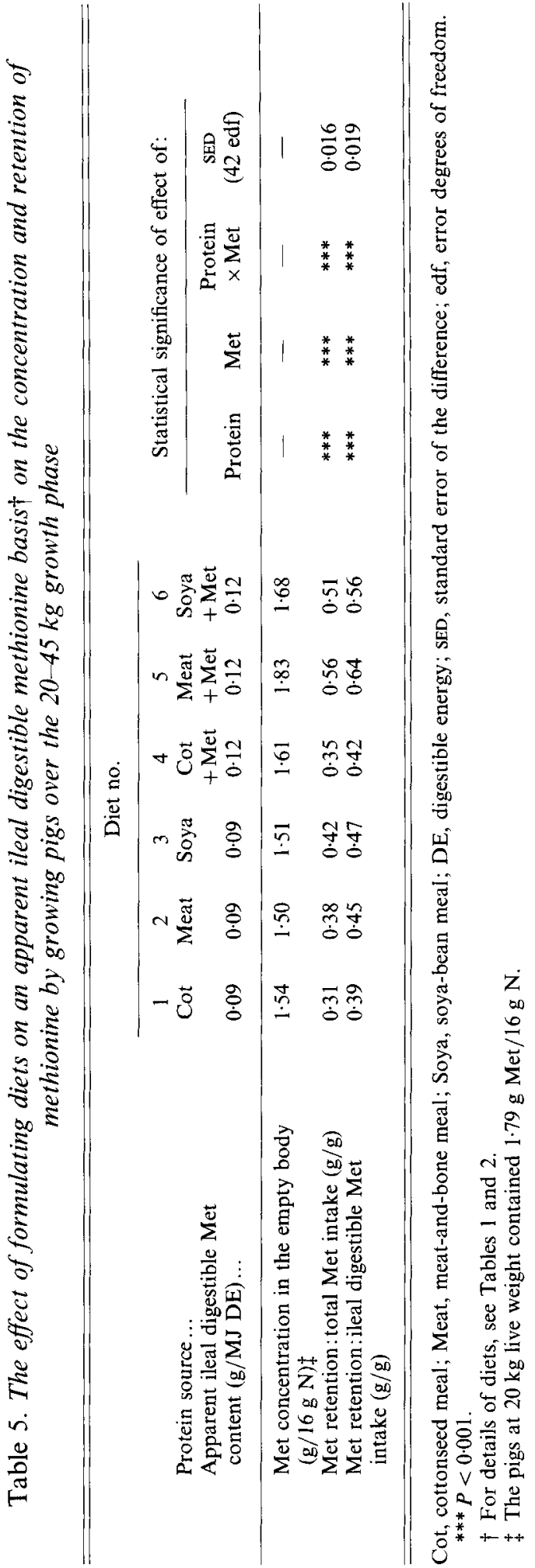




\section{RESULTS}

One pig given diet $2(\mathrm{MBM})$ grew slowly and its results were treated as missing plots in the statistical analyses. All other pigs remained healthy during the experiment.

Growth rates of the pigs given the cottonseed meal $(411 \mathrm{~g} / \mathrm{d})$ and meat-and-bone meal (442) diets and formulated to $0.09 \mathrm{~g}$ ileal digestible methionine/MJ DE were significantly lower $(P<0.05)$ than for pigs given the soya-bean meal diet (496) (Table 3). The addition of methionine to the three diets increased growth rates and lowered the FCR $(P<0 \cdot 001)$.

Crude protein $(\mathrm{N} \times 6.25)$ deposition was greater in the pigs given soya-bean meal $(61 \mathrm{~g} / \mathrm{d})$ and meat-and-bone meal $(57)$ relative to those given cottonseed meal $(47 ; P<$ 0.05 ; Table 4$)$. The crude protein content in the empty bodies was also affected by protein source $(P<0.001)$ and was increased by methionine supplementation $(P<0.001)$.

There were also small effects of protein source and methionine supplementation on the fat and energy composition of the empty bodies $(P<0 \cdot 001$, Table 4$)$ and small effects of protein source on fat and energy deposition rates $(P<0.05, P<0.01)$. However, energy retained:DE intake was similar for the three protein sources supplemented with methionine $(0 \cdot 39-0 \cdot 41, P>0 \cdot 05)$.

There was a trend for the methionine content in the pigs supplemented with methionine $(1.61-1.83 \mathrm{~g} / 16 \mathrm{~g} \mathrm{~N})$ to be higher than those unsupplemented (1.50-1.54; Table 5).

Retention of ileal digestible methionine was low for all three treatments: $0 \cdot 39,0.45$ and 0.47 for pigs given cottonseed meal, meat-and-bone meal and soya-bean meal respectively (diets 1-3; Table 5). Methionine retention was higher for the methionine-supplemented pigs $(P<0.001)$.

\section{DISCUSSION}

The significant responses in growth and protein deposition of the pigs to supplements of methionine in diets 4-6 confirmed that methionine was the limiting amino acid in diets $1-3$. The results indicate that there are considerable differences in the growth response of pigs given similar levels of ileal digestible methionine. Growth response was $496 \mathrm{~g} / \mathrm{d}$ for pigs given soya-bean meal relative to $411 \mathrm{~g} / \mathrm{d}$ for those given cottonseed meal (Table 3 ). Protein deposition was also superior $(61 v .47 \mathrm{~g} / \mathrm{d}$, Table 4$)$. The difference in retention of ileal digestible methionine, however, was much smaller $(0.47 v .0 .39)$ for pigs given soya-bean and cottonseed meals respectively (Table 5). These results indicate that a proportion of the ileal digestible methionine in cottonseed meal was inefficiently utilized. These results are similar to those reported previously for lysine (Batterham et al. 1990a) and threonine (Beech et al. 1991). It appears that, as with these amino acids, heat damage to methionine can induce changes which, although not affecting ileal digestibility, depress utilization. These results support earlier findings that the nature of the heat damage in cottonseed meal is not specific to the free $\epsilon$-group of lysine but most probably involves reactions between amino acids within the protein molecule (Batterham et al. 1981). However, with methionine the differences in growth performances of the pigs given the three diets were smaller (411 v. $496 \mathrm{~g} / \mathrm{d})$ than those of pigs given lysine-deficient diets $(377$ v. 541; Batterham et al. $1990 \mathrm{a}$ ), and overall differences in methionine retention were less (methionine retention $0.39-0.47$; lysine retention $0.36-0.75$ ). It is possible that the changes to methionine availability may be less severe than those to lysine, where availability varies from approximately 0.40 for cottonseed meal to 0.88 for soya-bean meal (Standing Committee on Agriculture, 1987).

The concentration of methionine in the methionine-deficient diets appeared to affect the methionine concentration of the protein of the pigs. The methionine concentration in the protein of pigs given the $0.09 \mathrm{~g}$ ileal digestible methionine $/ \mathrm{kg}$ diets varied from 1.50 to 
$1.54 \mathrm{~g} / 16 \mathrm{~g} \mathrm{~N}$ and was higher in the pigs given $0.12 \mathrm{~g}$ ileal digestible methionine $(1.61-1.83$; Table 5). A similar effect was reported with lysine (Batterham et al. 1990a). Overall, the levels of methionine in the protein of the pigs given the methionine-deficient diets were lower than those reported in the literature for young or weaner pigs given a variety of diets $(1.97-2.59 \mathrm{~g} / 16 \mathrm{~g} \mathrm{~N}$, Wilson \& Leibholz, 1981; 1.62-1.87, Zhang et al. 1986; 1.80-1.94, Campbell et al. 1988) and for grower pigs (1.67-2.07, Batterham et al. 1990 b).

The methionine retention results are different from those for lysine (Batterham et al. $1990 a$ ) in that for pigs fed on diets 1-3 (unsupplemented) there were only small differences in retention, despite moderate differences in growth, and overall retentions were low. Furthermore, there were considerable increases in retentions for pigs fed on diets 5 and 6 (supplemented with methionine). With lysine there were large differences in the retention of pigs given the unsupplemented lysine diets and little or no improvement in retention with lysine supplementation. These differences in methionine retention levels indicate there is a need to define the overall relationship between dietary methionine concentration and methionine retention, as was done with lysine (Batterham et al. 1990 b).

The retention values for ileal digestible methionine in the current experiment $(0 \cdot 39-0.64)$ are also much lower than the estimated values reported by Leibholz (1985) (0.97-1.07). Leibholz (1985), however, calculated retention using estimated values for methionine concentration from previous experiments where the pigs appeared to have been given largely methionine-adequate diets. The current results show that methionine concentration in the empty body is affected by dietary methionine concentration and the use of literature values could result in considerable overestimation of retention values.

There were also small effects of protein source and methionine supplementation on the concentrations of fat and energy in the empty bodies of the pigs $(P<0.05)$. This would be expected as protein concentration had been affected by these treatments. However, the retention of energy in the empty body: DE intake was similar $(0.39-0.41 ; P>0.05)$ for pigs given diets 4-6 (supplemented with methionine). These were the more nutritionally balanced diets and the similar retentions of energy indicates that the estimated dietary energy concentrations had been achieved.

Overall, the results indicate that values for the ileal digestibility of methionine in heatdamaged protein concentrates are unsuitable for dietary formulation. It appears that a proportion of the ileal digestible methionine may be absorbed in a form(s) that is (are) inefficiently utilized. Thus, the assay is not a reliable indicator of methionine availability in heat-processed meals. The results also indicate that the differences in methionine availability between the three meals may be slightly less than the differences in lysine availability. Thus, lysine availability may overestimate methionine availability. There is a need to develop separate assays for determining the availability of methionine in protein concentrates.

The authors are grateful to Messrs R. C. Wilson and A. W. Davis for management of the pigs and skilled technical assistance, Ms E. B. Dettmann and Ms E. J. White for assistance with statistical analyses, and Ajinomoto Co. Inc., Japan for the supply of amino acids. This work was supported by financial grants from the Pig Research and Development Corporation.

\section{REFERENCES}

Agricultural Research Council (1981). The Nutrient Requirements of Pigs. Slough: Commonwealth Agricultural Bureaux.

Andrews, R. P. \& Baldar, N. A. (1985). Amino acid analysis of feed constituents. Science Tools 32, $44-48$.

Batterham, E. S., Andersen, L. M., Baigent, D. R., Beech, S. A.\& Elliott, R. (1990a). Utilization of ileal digestible amino acids by pigs: lysine. British Journal of Nutrition 64, 679-690.

Batterham, E. S., Andersen, L. M., Baigent, D. R. \& White, E. (1990 b). Utilization of ileal digestible amino acids 
by growing pigs: effect of dietary lysine concentration on efficiency of lysine retention. British Journal of Nutrition 64, 81-94.

Batterham, E. S. \& Murison, R. D. (1981). Utilization of free lysine by growing pigs. British Journal of Nutrition 46, 87-92.

Batterham, E. S., Murison, R. D. \& Lowe, R. F. (1981). Availability of lysine in vegetable protein concentrates as determined by the slope-ratio assay with growing pigs and rats and by chemical techniques. British Journal of Nutrition $45,401-410$.

Beech, S. A., Batterham, E. S. \& Elliott, R. (1991). Utilization of ileal digestible amino acids by growing pigs: threonine. British Journal of Nutrition 65, 381-390.

Black, J. L., Campbell, R. G., Williams, I. H., James, K. J. \& Davies, G. T. (1986). Simulation of energy and amino acid utilization in the pig. Research and Development in Agriculture 3, 121-145.

Burlacu, G., Baia, G., lonila, D., Moisa, D., Tascenco, V., Visan, I. \& Stoica, I. (1973). Efficiency of the utilization of the energy of food in piglets after weaning. Journal of Agricultural Science, Cambridge 81, 295-302.

Campbell, R. G., Taverner, M. R. \& Rayner, C. J. (1988). The tissue and dietary protein and amino acid requirements of pigs from $8 \cdot 0$ to $20 \cdot 0 \mathrm{~kg}$ live weight. Animal Production 46, 283-290.

Fuller, M. F. \& Wang, T. C. (1987). Amino acid requirements of the growing pig. In Manipulating Pig Production, pp. 97-111 [J. L. Barnett, E. S. Batterham, G. M. Cronin, C. Hansen, P. H. Hemsworth, D. P. Hennessy, P. E. Hughes, N. E. Johnston and R. H. King, editors]. Werribee: Australasian Pig Science Association.

Jordan, J. W. \& Brown, W. O. (1970). The retention of energy and protein in the baby pig fed on cows milk. In Energy Metabolism of Farm Animals, pp. 161-164 [A. Schurch and C. Wenk, editors]. Zurich: Juris Druck and Verlag.

Leibholz, J. (1985). The digestion of protein in young pigs and the utilization of dietary methionine. British Journal of Nutrition 53, 137-147.

Mason, V. C., Bech-Andersen, S. \& Rudemo, M. (1980). Hydrolysate preparation for amino acid determinations in feed constituents. 8. Studies of oxidation conditions for streamlined procedures. Zeitschrift für Tierphysiologie, Tierernährung und Futtermittelkunde 43, 146-164.

Standing Committee on Agriculture (1987). Feeding Standards for Australian Livestock. Pigs. East Melbourne: CSIRO.

Tanksley, T. D. \& Knabe, D. A. (1981). Use of cottonseed meal in swine rations. Feedstuffs 53, $24-27$.

Wilson, R. H. \& Leibholz, J. (1981). Digestion in the pig between 7 and $35 \mathrm{~d}$ of age. 5. The incorporation of amino acids absorbed in the small intestines into the empty-body gain of pigs given milk or soya-bean proteins. British Journal of Nutrition 45, 359-366.

Zhang, Y., Partridge, I. G. \& Mitchell, K. G. (1986). The effect of dietary energy level and protein: energy ratio on nitrogen and energy balance, performance and carcass composition of pigs weaned at 3 weeks of age. Animal Production 42, 389-395. 